\title{
THE ENGLISH READING HABITS OF GRADUATE STUDENTS AT DALIAN UNIVERSITY OF TECHNOLOGY, CHINA
}

\author{
Muhammad Farshad* \\ Uzma Murad Panhwar ${ }^{\dagger}$ \\ Abida Siddiqui ${ }^{\ddagger}$
}

\begin{abstract}
The study is set to know, analyze, and finally realize the reading habits of the students at Dalian University of Technology (DUT), specifically the English language (L2). The study aims to find out the reading habits of the students. Five-point Likert scale questionnaire was made to investigate the participants' general attitudes towards reading and their reading preferences. 12000 questionnaires were distributed out of which 641 were returned after being filled in. The data collected through the questionnaire were analyzed using SPSS Statistics 20 program. It is made out of the conducted survey that the students at DUT have healthy reading habits and their attitude towards reading is positive. Moreover, it is made out that the reading habits of the students have a remarkable impact on their academic performances. The research in the end has made some suggestions and recommendations to foster reading habits and attitudes among university students for better language proficiency.
\end{abstract}

Keywords: $\quad$ Reading habits, Attitudes; Academic performance, Reading preferences

\section{INTRODUCTION}

It is widely believed that reading is one of the best things to get our learned knowledge from. Moreover, reading in a language, which is

*Ph.D. Scholar, Central China Normal University, Wuhan PRC. Email: panhwar.farshad@gmail.com (Corresponding author)

${ }^{+}$Assistant Professor, Department of EMS, Faculty of Education, University of Sindh. Email: uzma_panhwar@yahoo.com $\ddagger$ Associate Professor, Department of Education, University of Sindh. Email: abida.siddiqui@usindh.edu.pk 
known as a global language and considered as a source of international bondage, would be bringing up more and more updated information and knowledge. To some of us, English is the mother tongue and to most of us, it is either a Second or Foreign Language. This research aims to know the English reading habits of the students at the DUT. Reading habits and attitudes may also vary from gender to gender. In some cultures, societies and regions females read more than males, while in other males read more than females.

This research is based on a presumption that reading habits, if positive, have a constructive impact on the academic performance of the students, specifically, language proficiency. Morrow and Young (1997) validating the Holdaway's developmental learning theory (Holdaway, 1982) suggest that the process of becoming literate includes a rich reading environment full of abundant materials, individualized activities, as well as peer and adult interactions around texts. Although this theory does not address reading habits and attitudes, specifically, it does include individualized reading activities as a necessary component of literacy development. Reading habits and attitudes could be enhanced with abundant materials made available to students, as well as peer and adult interactions. The incidental information acquisition theory states that students pick up knowledge incidentally through reading and that knowledge or information can be used to serve a purpose later (Moyer, 2007).

This theory indicated that reading could lead to a wealth of schema for students to have and use throughout their educational learning and life experiences. The acclamation of schema through participating in reading as a leisure activity is of a great benefit for the students' educational growth. Reading habits and attitudes can be connected to parts of many theories, but review of the literature did not find any theories about why some students engaged have healthy and positive reading habits and attitudes, while others do not have. This question leads us to seek out more literature in search of theories, which can be used as a theoretical framework for my thesis study. 
Bamford and Day (1998) argue that learners' reading habit is seemed to emanate from perceptions acquired from people's reading history and experience (as cited in Guthrie \& Greaney, 1996). This is how one can always acquire the reading habit by continuous effort and practice. It can help one to get a good academic reputation, higher grades, good reading skills, language fluency, and better future perspectives.

Now reading habits are transferred to children as somewhat inheritance too from the parents. If the parents are good readers and have a collection of good books at home, discuss about books at home, love going to the library often to read and appreciate their children to be involved in reading activities then it is a source of inspiration and encouragement for the younger children.

The habit of reading good contents daily act as an exercise for students' mind and keep them mentally fit and flexible. If students have never tried it, then always remember that it is never too late to start a good habit. Parents overall are, for sure, role models for their children and children imitate their parents. However, parents, regarding reading habits, make a great impact on the development of reading habits and attitudes of their children in the future. It was found out through an earlier research that not only students' reading habits but also their attitude towards reading defines their language proficiency, which would result in affecting students' academic performance (Guthrie \& Greaney, 1996). Both the teachers and the students have to decide how they would make it convenient for themselves to teach and learn the language (Morrow \& Young, 1997).

The study reveals some important aspects related to reading habits, reading attitudes, and their relationship with English language proficiency. According to the Theory of Sociolinguistics, we are supposed to see reading as a social and cultural activity. Shared reading can be one of the applications of the theory, which states that shared reading or buddy reading can certainly make the reader's 
language proficient.

This study can be seen as significant in providing useful information that can assist the university management, teachers, and the students to realize the real-time reading habits and attitudes of the students in DUT. Moreover, the research will help the teachers and the university management to get better the students' reading habits. In addition to this, the future study will be covering all the aspects affecting the reading habits of the students at DUT and can recommend how can be they made better. The study addresses following questions:

- What are the participants' reading habits?

- What is the relationship between the students' reading habits and students' academic performance specifically language proficiency?

\section{RESEARCH METHOD}

The research was conducted through a 5 points Likert scale survey questionnaire. The questionnaire was based on 5 points Likert scale, which is 5-1 (i.e. 5=Strongly Agree, 4=Agree, 3=Uncertain, 2=Disagree, $1=$ Strongly Disagree). The questionnaire consisted of 50 statements, 20 related to reading habits; 20 related to reading attitudes and 10 related to readings' impact on academic performance. Moreover, a short one to one interviews were also conducted to get knowledge about some basic facts regarding the impacts of reading on language proficiency. 641 students were chosen randomly out of 12000 graduate students at DUT. These 641 cases were analysed using SPSS. The final discussion and conclusion are based on the findings of the survey and interviews.

\section{Sample size}

The total population of graduate students at DUT is 12000 , for the survey the sample size is calculated using an online tool (Marra \& Bogue, 2006). As per the sample, calculating tool 629 was the required 
sample number, while 641 respondents responded to the questionnaire successfully. Statistical Package for Social Science (SPSS), version 20 was used for data analysis purpose (Karim, 2006). The tools like mean, median, standard deviation, Cronbach's alpha, and graphical representation were used.

\section{Survey questionnaire}

A pilot survey was conducted to determine the reliability of the questionnaire. This pilot study showed that the Cronbach Alpha is 0.747 , which is more than 0.7 . This means the questionnaire is reliable.

\section{Table 1 Reliability Statistics}

Cronbach's Alpha

.747

After receiving all the filled in questionnaires, eight students were selected for face-to-face interviews (04 male and female from masters and $\mathrm{PhD}$ programmes). Following were the major questions of interview schedule:

- Do you think reading is helping you in getting good grades?

- Do you believe reading helps you in improving academic performance (language proficiency)?

- How language proficiency can be improved by reading?

- What aspects of language are learned through reading?

- Do you believe reading habits and attitudes affect our future or help us in getting better jobs?

\section{DATA ANALYSIS AND DISCUSSION}

The respondents have responded in wide diversity ranging from 1 to 5 on the Likert scale against the statement 'I read every day', which means from 'Strongly Disagree' to 'Strongly Agree'. Regardless of this wide range of differences in opinion, the majority of the respondents believe they read every day. Out of the 641 respondents, 44.77 per 
cent 'Agree' with the statement. 23.87 per cent of the respondents 'Strongly Agree' with the statement. 17.94 per cent is 'Uncertain' about the statement. 10.76 per cent 'Disagree' with the statement. While 2.65 per cent 'Strongly Disagree' with the statement. So, by summing up 'Agree' and 'Strongly Agree', which makes 68.64 per cent. We can say clearly that the majority of students at DUT read every day, which means they have positive reading habits.

The statement goes as 'I read at my school's library'. The respondents have responded in wide diversity ranging from 1 to 5 on the Likert scale, which means from 'Strongly Disagree' to 'Strongly Agree'. The response is quite amalgamated. Out of the 641 respondents, 31.20 per cent of the 'Agree' with the statement. 8.89per cent of the respondents 'Strongly Agree' to the statement. 24.84 per cent is 'Uncertain' about the statement. 22.15 per cent 'Disagree' to the statement. While 15.91 per cent 'Strongly Disagree' with the statement. Even though 40per cent of the respondents 'Agree' and 'Strongly Agree' with the statement, but that does not make a clear-cut majority. Therefore, there is no certain lead where the students read. We can say that majority of students at DUT are not sure if they read at the school's library.

The responses against the statement 'Every week I read at least twice' were ranging in wide diversity ranging from 1 to 5 on the Likert scale. The majority of the respondents believe that they do read at least twice, a week. Out of the 641 respondents, 30.73 per cent 'Agree' with the statement. 30.58 per cent of the respondents 'Strongly Agree' to the statement. 27.15 per cent is 'Uncertain' about the statement. 10.14 per cent 'Disagree' with the statement. While 1.40 per cent 'Strongly Disagree' with the statement. So, by summing up 'Agree' and 'Strongly Agree', which makes 61.31 per cent. Though there is always a difference of opinion in the masses, we would surely go with the majority. We can say clearly that the majority of students at DUT read at least twice, Every Week. So it is made out they have positive reading habits. 
Out of the 641 respondents, 30.11 per cent responses were 'Agree'. 8.42 per cent 'Strongly Agree', 28.24 per cent 'Uncertain', 22.93 per cent 'Disagree' while 10.30 per cent 'Strongly Disagree' with the statement 'I read a book when I go to bed'. Thus, 38.53 per cent, of the respondents at DUT do not read a book before going to the bed. On the contrary, majority of responses, 56 per cent, were in the favour of the statement 'I read whenever I have free time'. Regardless of this wide range of differences in opinion, the majority of the respondents believe that they read more than one book. Out of the 641 respondents, 48.52 per cent 'Agree' to the statement 11.39 per cent of the respondents 'Strongly Agree' with the statement. 18.10 per cent is 'Uncertain' about the statement. 14.20 per cent 'Disagree' with the statement. While 7.80 per cent 'Strongly Disagree' with the statement.

Responses against the statement 'when I am home on vacation, I read a lot' showed that 47.11 per cent agreed, 15.76 per cent strongly agreed with the above mentioned statement. By summing up 'Agree' and 'Strongly Agree', which makes 62.87per cent, it can be concluded that a certain majority of students at DUT read a lot when they are home, on vacation.

\section{Findings regarding students' reading habits}

It was found that the students at DUT have healthy reading habits. 68 per cent of the students at DUT believe that they read every day, which is a good number to be said the majority reads every day. While 61 per cent of the students believe that they at least read twice a week. On the other hand, 70 per cent of the students here make use of Electronic/Digital devices to be done with their everyday reading, so it means the students have a good trend of following the smooth swift of technology. 70 per cent of the students believe, they read more than one book a time sometimes. 47 per cent of the students at DUT believe they prefer reading to watching television, which means reading culture is prevailing in DUT. 57 per cent of the students at DUT believe that they have read an entire book in the last six months, this 
brings before their reading consistency. The majority of the students are 'Uncertain' about if they read at the school's library; they believe that they read at variety of places like classrooms, the school library, coffee shop, and their dormitory. 55 per cent of the students at DUT believe that they read books written in English, which shows their interest in second language acquisition. 54 per cent of the students at DUT believe that they do most of their readings on computers, which means they find it more convenient to read online than to read from books these days. 52 per cent of the students at DUT believe that read more in their mother tongue. The majority of the students at DUT are 'uncertain' about if they would read when they go to bed. 52 per cent of the students at DUT 'Disagree' only reading at classrooms, they believe that they read at a variety of places not only classrooms. 56 per cent of the students at DUT believe that they would note down the names if they hear about a new book. Also, 56 per cent of the students at DUT believe that they would read whenever they have free time. Contrary to that, 57 per cent of the students at DUT 'Disagree' to if they only read when asked by the teacher. 61 per cent of the students at DUT believe that read only what interests them. The majority of the students at DUT Are Uncertain about if they read more fiction than non-fiction. 57 per cent of the students at DUT believe that they read fast and can finish books quickly. Lastly, 48 per cent of the students at DUT believe that they sometimes spend all night reading, if the book is interesting. To sum up, the students here have good reading habits. Having healthy reading habits may also help students improving their English language proficiency.

The most important finding is; the students believe that reading makes their English better. In other words, the students believe that reading helps improve their English proficiency. To sum up, the findings are significant enough to say that the students at DUT have good reading habits. Their attitudes toward reading are also positive. They believe that they do enough reading, and certainly, the readings do help them in language proficiency. We can say that reading habits, 
reading attitudes and academic performance specifically language proficiency have strong relationships with one another.

\section{Limitation of the study and future work}

The study is limited to a small number of students. The only language skills tested ate reading habits, reading attitudes, and language proficiency. Another limitation was related to the interpretation of the questionnaire. The word may have been interpreted differently by different students. Only, L2 (English) is taken into consideration. Therefore, the study is quite limited, but in future work, the study can be expanded to all the students at DUT. The future work can be the students' reading habits, reading attitudes, and their English language proficiency and competence at DUT concerning gender and department-based.

\section{CONCLUSION}

The study has come to conclude that the graduate students at DUT have their reading habits up to the mark. The research also brings to notice the relationship between reading habits, reading attitudes, and academic performance specifically English language proficiency. The students have proper reading habits and attitudes, inside and outside the classrooms helping them with academics. The students believe that reading makes their English better. They spend a good time reading English. Though new and difficult words are the hardest part for them in reading, yet they prefer reading to watching television. The majority of the students have read an entire book in the last six months. The graduate students at DUT read not only in their classroom. This is the time of technology, so the students do most of their reading on a computer, but they still feel more comfortable reading from books. The students disagree with the idea that reading is boring, and makes them feel tired and sleepy. Moreover, the students stand with the idea that reading is one of the best things to get knowledge. The students here manage their readings, they take 
notes, use highlighters, make reading lists, and read the books they like. They even note the names of the new books they come to know. Students strongly believe that reading provides them with pleasure. They believe in shared reading and feel good about helping other students with reading problems. The students discuss good books amongst each other. They read more when they are back home on vacations, and want to own a lot of books of their own. The students at DUT manage their readings they make reading lists and often note down the names of the new books they come to know. The students take notes while they read and often use a highlighter to mark the important parts in the text. The students read what interests them. The students at DUT use highlighter when they read. The students at DUT at least read twice a week. The students discuss good books with their friends. The majority of students consider themselves as good readers. The most important finding is; the students believe that reading makes their English better. In other words, the students believe reading helps them improve their English proficiency.

The findings regarding the influence of reading on language proficiency. The research has shown a certain relation between reading and language proficiency. 72 per cent of the students at DUT believe that reading is one of the best things, which means they have strong belief reading gives them knowledge, and knowledge leads to academic excellence and language proficiency. 41 per cent of the students believe it is hard for them to read and understand some words in English, which means when they read they learn a lot of new words, ultimately improving their vocabulary and English language proficiency. 53 per cent of the students at DUT believe that they feel comfortable reading in their mother tongue, which means they need more to do with a second language. If they get through it, they get proficiency in the second language, ultimately helping them improving English language proficiency. 53per cent of the students at DUT believe they do not only read to get good grades, but academic excellence and knowledge. 86 per cent of the students at DUT believe 
that reading makes their English better, ultimately exposing them to a greater world of knowledge. The majority of the students believe that they read not only related to their major but also extensively which exposes them to greater knowledge helping them to thrive in academic matters. Reading itself helps a lot in improving the language proficiency and academic performance of the students. It teaches many things, which can make them a keen learner like; 63 per cent of the students believe that they manage their readings, 58 per cent of the students at DUT believe that they take notes while reading, 55 per cent of the students at DUT believe that they make a reading list and read the books they like. Finally, 59 per cent of the students at DUT believe that they use a highlighter when they read; all these make them a better reader, helping them to improve their general reading habits, getting them closer to the acquisition of knowledge, ultimately making their English language proficient. Therefore, it can be said reading has a certain relationship with English language proficiency and the ones who are good readers will certainly be good language learners.

To sum up, the students at DUT have healthy reading habits. They also have a positive attitude towards reading. The students also have a strong belief that positive reading habits and reading attitude can help them improve their language proficiency. The students who have good reading habits and positive reading attitudes will become a keen reader and will be exposed to knowledge. The language proficiency of these students, who have good reading habits, is good that ultimately helps them in improving English language proficiency and academic performance.

\section{REFERENCES}

Ahmed, S. (2016). Reading habits and attitudes of UMSKAL undergraduates. International Journal of Applied Linguistics and English Literature, 5(2), 189-201. 
Bamford, J., \& Day, R. R. (1998). Teaching reading. Annual Review of Applied Linguistics, 18, 124-141.

Guthrie, J. T., \& Greaney, V. (1996). Literacy acts. In R. Barr, M. L., Kamil, P. D., Pearson, \& P. B., Mosenthal (Eds.) Handbook of reading research (pp. 68-96). Psychology Press.

Holdaway, D. (1982). Shared book experience: Teaching reading using favorite books. Theory into Practice, 21(4), 293-300.

Karim, N. S. A. (2006). Reading habits and attitude in Malaysia: Analysis of gender and academic programme differences, Kekal Abadi, 25(1/2), 16-24.

Marra, R. M., \& Bogue, B. (2006). A critical assessment of online survey tools. Women in Engineering ProActive Network. Retrieved from: file://C:/Users/Mukesh\%20Kumar/ Downloads/58473-Article\%20Text-58312-1-10-20121217.pdf

Morrow, L. M., \& Young, J. (1997). A family literacy program connecting school and home: Effects on attitude, motivation, and literacy achievement. Journal of Educational Psychology, 89(4), 736-742.

Moyer, A. (2007). Do language attitudes determine accent? A study of bilinguals in the USA. Journal of Multilingual and Multicultural Development, 28(6), 502-518. 